\title{
Kolmannen säilörehusadon kehitysrytmi ja viljelytekniset ratkaisut
}

\author{
Maarit Hyrkäs ${ }^{1)}$, Perttu Virkajärvi ${ }^{1)}$, Auvo Sairanen ${ }^{1)}$, Raija Suomela ${ }^{2)}$, Sirkka Luoma ${ }^{2)}$ ja Minna \\ Toivakka ${ }^{3}$ \\ ${ }^{1)}$ Luonnonvarakeskus, Vihreä teknologia, Halolantie 31 A, 71750 Maaninka, etunimi.sukunimi@luke.fi \\ ${ }^{2)}$ Luonnonvarakeskus, Vihreä teknologia, Tutkimusasemantie 15, 92400 Ruukki, \\ etunimi.sukunimi@luke.fi \\ ${ }^{3)}$ Yara Suomi Oy, etunimi.sukunimi@yara.com
}

\section{Tiivistelmä}

Kolmen korjuun strategia säilörehunurmilla kasvattaa jatkuvasti suosiotaan myös pohjoisemmassa Suomessa. Ilmastonmuutoksen myötä pidentyvät kasvukaudet ja jälkikasvultaan hyvät lajikkeet pakottavat siirtymään kolmen korjuun taktiikkaan lämpiminä syksyinä, jos rehun sulavuuden haluaa pitää korkeana ja samalla välttää talveksi peltoon jäävää odelmaa. Kolmannen sadon kehitys poikkeaa selvästi ensimmäisestä ja toisesta sadosta, eikä sitä tunneta vielä kovin hyvin. Tässä artikkelissa kootaan yhteen useamman Luonnonvarakeskuksessa toteutetun korjuuaikastrategiakokeen tuottama tieto kolmannen sadon ominaisuuksista.

Aineistona käytettiin kolmea eri koesarjaa. Kenttäkokeita oli yhteensä kuusi, ja ne olivat kolme tai nelivuotisia ajoittuen välille 2009-2015. Kokeista kolme toteutettiin Maaningalla (viljelyvyöhyke III), kaksi Ruukissa ja yksi Sotkamossa (viljelyvyöhyke IV). Aikavälille sisältyi niin lämpimiä, viileitä, kuivia kuin sateisiakin kesiä. Kasvilajeina olivat timotei, nurminata tai yleisimmin näiden seos. Toisen korjuun ajankohta vaihteli heinäkuun puolesta välistä elokuun puoleen väliin, ja kolmannen korjuun ajankohta elokuun loppupuolelta lokakuun alkuun saakka. Kokeet lannoitettiin väkilannoitteilla maan viljavuusluokka huomioiden. Kolmas sato sai typpeä $30-55 \mathrm{~kg} / \mathrm{ha}$ sekä kaliumia $0-30 \mathrm{~kg} / \mathrm{ha}$ kokeesta riippuen. Kokeet toteutettiin lohkoittain satunnaistettuina tai osaosaruutukokeina kolmena tai neljänä kerranteena $10-12 \mathrm{~m}^{2}: n$ kokoisilla koeruuduilla. Kokeissa oli erilaisia korjuuaikastrategioita sekä kokeesta riippuen muina koetekijöinä erilainen lannoitus tai lajikeseos. Kaikista kokeista määritettiin kuiva-ainesato sekä D-arvo, NDF ja raakavalkuainen ja osassa myös kivennäis- ja hivenainepitoisuudet.

Satotaso vaihteli alle tuhannesta kuiva-ainekilosta yli 4000 kuiva-ainekiloon hehtaaria kohden. Kolmannen sadon kasvunopeus oli hidasta verrattuna tyypillisiin ensimmäisen ja toisen sadon kasvunopeuksiin. Koska nurmen kasvu hidastuu syksyä kohden, kolmannen sadon satotasoa voidaan nostaa tehokkaammin aikaistamalla toista korjuuta, kuin myöhästyttämällä kolmatta korjuuta. Kuiva ajanjakso toisen sadon korjuun jälkeen heikentää kolmannen sadon kasvuun lähtöä, kun taas korjuuaikaan ongelmana on useammin liiallinen märkyys. Kolmas sato on yleisesti, kuten tässäkin tutkimuksessa, hyvin sulavaa eikä D-arvo alittanut suositusta $680 \mathrm{~g} / \mathrm{kg}$ ka. Kolmannen sadon korjuuajan valinnassa sääolosuhteet korostuvat rehun laadun muutosten ollessa hitaita. Korjuun ajoittamisella ja lannoituksella voi lisäksi olla vaikutusta nurmen talvehtimiseen.

Kolmannen sadon typpilannoitus pidetään yleisesti maltillisena talvituhojen välttämiseksi mutta käytännössä ympäristötukiehdot rajoittavat lannoitusta. Tässä tutkimuksessa valtaosa typpitaseista oli negatiivisia tai lähellä nollaa, joten nurmi käytti yhtä paljon tai enemmän typpeä kuin mitä sille lannoitteena annettiin.

Asiasanat: D-arvo, korjuuajankohta, nurminata, sato, timotei, typpitase 


\section{Johdanto}

Kolmen korjuun strategia säilörehunurmilla kasvattaa jatkuvasti suosiotaan myös pohjoisemmassa Suomessa. Ilmastonmuutoksen myötä pidentyvät kasvukaudet ja jälkikasvultaan hyvät lajikkeet pakottavat siirtymään kolmen korjuun taktiikkaan lämpiminä syksyinä, jos rehun sulavuuden haluaa pitää korkeana ja samalla välttää talveksi peltoon jäävää odelmaa. Kolmella korjuulla on mahdollista päästä yhtä aikaa sekä korkeaan satotasoon että korkeaan sulavuuteen, mikäli kolmas sato onnistuu hyvin. Kolmannen sadon kehitys poikkeaa selvästi ensimmäisestä ja toisesta sadosta, eikä sitä tunneta vielä kovin hyvin. Tässä artikkelissa kootaan yhteen useamman Luonnonvarakeskuksessa toteutetun korjuuaikastrategiakokeen aineisto, ja selvitetään mitkä tekijät selittivät kuiva-ainesadon kehitystä, kuinka sadon laatuparametrit muuttuivat kasvuajan pidentyessä ja kuinka hyvin kolmas sato hyödynsi saamansa typpilannoituksen.

\section{Aineisto ja menetelmät}

Aineistona käytettiin kolmea eri koesarjaa, joista kukin sisälsi kenttäkokeen kahdella paikkakunnalla (Taulukko 1). Kokeita oli siis yhteensä kuusi, ja ne olivat kolme tai nelivuotisia ajoittuen välille 20092015. Kaikki kokeet oli perustettu koetta edeltävänä kesänä käyttäen ohraa suojaviljana. Kokeista kolme toteutettiin Maaningalla (Pohjois-Savo; viljelyvyöhyke III), kaksi Ruukissa (PohjoisPohjanmaa; viljelyvyöhyke IV) ja yksi Sotkamossa (Kainuu; viljelyvyöhyke IV).

Taulukko 1. Aineiston kuvaus.

\begin{tabular}{cccccccc} 
Sarja & Koe & Koevuodet & Koepaikka & Kasvilaji & $\begin{array}{c}\text { Korjuuaikoja } \\
\text { 3. sadossa }\end{array}$ & Muu koekäsittely & $\mathrm{n}$ \\
\hline 1 & 1 & $2009-2012$ & Maaninka & timotei-nurminata & 1 & - & 3 \\
1 & 2 & $2009-2012$ & Ruukki & timotei & 1 & - & 4 \\
2 & 3 & $2013-2015$ & Maaninka & timotei ja nurminata & 2 & 2 lannoitustasoa & 24 \\
2 & 4 & $2013-2015$ & Ruukki & timotei-nurminata & 2 & 2 lannoitustasoa & 10 \\
3 & 5 & $2013-2015$ & Maaninka & timotei-nurminata & 2 & 3 lajikeseosta & 18 \\
3 & 6 & $2013-2015$ & Sotkamo & timotei-nurminata & 2 & 3 lajikeseosta & 18 \\
\hline
\end{tabular}

Korjuustrategiakokeissa 1 ja 2 oli vain yksi koejäsen, josta tehtiin kolme niittoa kasvukaudessa. Koe toteutettiin Maaningalla hietamaalla timotei-nurminataseoksena (Tuure-Ilmari) kolmena kerranteena ja Ruukissa multamaalla puhtaana timoteina (Iki) neljänä kerranteena. Koe 3 toteutettiin Maaningalla erikseen puhtaina timotei- ja nurminatakasvustoina (Tenho ja Inkeri, maalaji HtMr) ja koe 4 Ruukissa timotei-nurminataseoksena (Nuutti-Inkeri, maalaji KHt). Koeasetelma oli lohkoittain satunnaistettu koe, jossa koejäseninä oli kaksi erilaista lannoitusstrategiaa sekä kaksi erilaista toisen korjuun ajankohtaa (aikainen ja myöhäinen) siten, että näistä muodostui neljä koejäsentä. Myös kolmannen korjuun ajankohta erosi siten, että aikaisen toisen korjuun koejäsenet niitettiin hieman aiemmin. Lannoitus poikkesi typen (30 tai $40 \mathrm{~kg} \mathrm{~N} / \mathrm{ha}$ ) lisäksi myös fosforin, kaliumin ja rikin määrässä. Kokeet 5 ja 6 olivat keskenään täysin samanlaiset ja ne toteutettiin Maaningalla (maalaji KHt) ja Sotkamossa (maalaji He). Koko kokeen koeasetelma oli osa-osaruutukoe, mutta kolmannen niiton osalta koe oli osaruutukoe. Pääruutuna oli kolme erilaista timotei-nurminataseosta (Tuure-Ilmari, Rubinia-Valtteri ja Grindstad-Inkeri) ja osaruutuna kolmannen korjuun ajankohta (syyskuun alku tai syyskuun loppu). Kokeissa 3-6 oli neljä kerrannetta. Kokeiden ruutukoko oli 10 tai $12 \mathrm{~m}^{2}$.

Toisen korjuun ajankohta vaihteli heinäkuun puolesta välistä elokuun puoleen väliin, ja kolmannen korjuun ajankohta elokuun loppupuolelta lokakuun alkuun saakka. Kokeet lannoitettiin väkilannoitteilla maan viljavuusluokka huomioiden. Kolmas sato sai typpeä $30-55 \mathrm{~kg} / \mathrm{ha}$ (keskimäärin $44 \mathrm{~kg} / \mathrm{ha}$ ), kaliumia $0-30 \mathrm{~kg} / \mathrm{ha}$ (keskimäärin $20 \mathrm{~kg} / \mathrm{ha}$ ) ja fosforia $0-5 \mathrm{~kg} / \mathrm{ha}$ (keskimäärin 1,4 kg/ha) kokeesta riippuen. Koeruuduilta määritettiin kuiva-ainesato sekä D-arvo, raakavalkuainen (rv) ja neutraalidetergenttikuitu (NDF). Kokeissa 1 ja 2 D-arvo määritettiin sellulaasiliukoisuuden ja tuhkan avulla, rv Kjeldahl-menetelmällä sekä NDF sintterillä MTT:n laboratoriossa Jokioisissa. Muissa 
kokeissa määritykset tehtiin Valio Oy:n laboratoriossa Seinäjoella NIR-menetelmällä. Näytteistä tehtiin kokeesta riippuen myös muita analyysejä, kuten kivennäis- ja hivenainemäärityksiä.

Käytettävä aineisto muodostettiin laskemalla jokaisen kokeen osalta kullekin koejäsenelle keskiarvot. Joitakin havaintorivejä ja yksittäisiä poikkeavia havaintoja poistettiin tarvittaessa. Näin muodostui aineisto, jossa oli yhteensä 77 riviä. Koepaikkojen päivittäinen keskilämpötila ja sademäärä saatiin Ilmatieteen laitoksen avoimesta datasta (www.ilmatieteenlaitos.fi/avoin-data). Säätietojen avulla laskettiin toisen ja kolmannen korjuun välisenä aikana kertynyt tehoisa lämpösumma (kasvuun vaikuttanut lämpösumma, ${ }^{\circ} \mathrm{C}$ vrk, lähtötaso $+5^{\circ} \mathrm{C}$ ), kasvuaikana kertynyt sadesumma $(\mathrm{mm})$, kaksi 15 vrk:n sadesummaa kasvuunlähtöhetken ympäriltä $(-7-+7$ vrk toisesta niitosta ja +14 vrk toisesta niitosta, mm) sekä keskilämpö ja keskisade kasvuaikana $\left({ }^{\circ} \mathrm{C} / \mathrm{vrk}\right.$ ja $\left.\mathrm{mm} / \mathrm{vrk}\right)$. Toisen ja kolmannen sadon korjuuhetki laskettiin vuorokausina toukokuun ensimmäisestä päivästä. Kasvuajan (2. niitosta 3. niittoon) lisäksi laskettiin päivien lukumäärä kolmannen sadon lannoitushetkestä kolmannen sadon niittoon.

Kuiva-ainesadolle etsittiin parasta selittäjää sovittamalla aineistoon regressiosuoria yhdellä tai useammalla selittäjällä. Tämä tehtiin SAS 9.3.-ohjelmiston Reg-proseduurilla. Lisäksi aineistosta piirrettiin kuvia MS Excel 2010-ohjelmalla ja sovitettiin kuviin regressiosuorat selitysasteineen.

\section{Tulokset ja tulosten tarkastelu}

\section{Kuiva-ainesato}

Kolmannen sadon satotaso vaihteli aineistossa välillä 790-4130 kg ka/ha (Taulukko 2). Sadon määrän, erilaisten sääolosuhteiden ja korjuiden ajoittamisen välisiä yhteyksiä selvitettiin regressiomalleilla, jotta tärkeimmät satoon vaikuttavat tekijät voitaisiin tunnistaa.

Ensimmäisessä sadossa kuiva-ainesadon kertymistä on mallinnettu esimerkiksi kasvuun vaikuttaneen lämpösumman, kasvupäivien lukumäärän ja kasvuajan keskimääräisen lämpötilan avulla (Rinne ym. 2010). Toisen ja kolmannen sadon kasvuun vaikuttaa lisäksi edellisen korjuun ajankohta. Toisin kuin yleensä ensimmäisessä sadossa, jälkisadoissa edellisen sadon korjuun aikaan vaivaavan kuivuuden voisi ajatella joissakin tilanteissa vaikuttavan negatiivisesti kasvuun lähtöön ja sitä kautta satotasoon. Tämän vuoksi yhdeksi selittäjäksi valittiin 15 vrk:n sadesumma toisen sadon korjuupäivästä laskien. Lisäksi kokeiltiin 15 vrk:n sadesummaa, jossa 2. niitto ajoittui jakson keskelle, mutta se ei selittänyt kuiva-ainesatoa eri tavalla kuin 15 vrk:n sademäärä 2. niitosta lukien. Ensimmäisen sadon korjuuajankohtaa ei huomioitu, koska tässä aineistossa tarkasteltiin vain kolmannen sadon kehitystä.

Taulukko 2. Korjuuajankohtien, lämpötila- ja sademäärätietojen, kolmannen sadon määrän ja sen ominaisuuksien kuvaus.

\begin{tabular}{llcccc} 
& & Minimi & Keskiarvo & Maksimi & Keskihajonta \\
\hline Toisen korjuun ajankohta & & 11.7. & 24.7. & 11.8. & \\
Kolmannen korjuun ajankohta & & 28.8. & 13.9. & 11.10. & \\
Päivien lkm 2. niitosta 3. niittoon & vrk & 26 & 51 & 77 & 13,2 \\
Päivien lkm lannoituksesta 3. niittoon & $\mathrm{vrk}$ & 22 & 48 & 74 & 13,6 \\
Keskilämpötila kasvuaikana & ${ }^{\circ} \mathrm{C} / \mathrm{vrk}$ & 11,2 & 14,8 & 17,5 & 1,42 \\
Keskimääräinen sade kasvuaikana & $\mathrm{mm} / \mathrm{vrk}$ & 1,0 & 2,2 & 3,1 & 0,37 \\
Kasvuun vaikuttanut lämpösumma & ${ }^{\circ} \mathrm{C}$ vrk & 249 & 488 & 696 & 118,1 \\
Sadesumma kasvuaikana & $\mathrm{mm}$ & 40 & 109 & 207 & 33,6 \\
Sademäärä 15 vrk 2. niitosta & $\mathrm{mm}$ & 4 & 34 & 60 & 14,0 \\
Kuiva-ainesato & $\mathrm{kg} \mathrm{ka} / \mathrm{ha}$ & 790 & 2600 & 4130 & 836 \\
D-arvo & $\mathrm{g} / \mathrm{kg} \mathrm{ka}$ & 682 & 716 & 758 & 19,9 \\
NDF & $\mathrm{g} / \mathrm{kg} \mathrm{ka}$ & 434 & 494 & 561 & 30,6 \\
Raakavalkuainen & $\mathrm{g} / \mathrm{kg} \mathrm{ka}$ & 78 & 125 & 198 & 29,1 \\
Typpitase & $\mathrm{kg} / \mathrm{ha}$ & -55 & -5 & 22 & 12,9 \\
\hline
\end{tabular}


Kuiva-ainesatoa selittävien muuttujien regressioyhtälöt ja niiden selitysasteet esitetään taulukossa 3. Selvästi parhaimmaksi selittäjäksi nousi toisen sadon korjuuaika $\left(R^{2}=0,72\right.$; Kuva 1a), kun taas kolmannen sadon korjuuajankohdalla ei ollut yhteyttä sadon määrään $\left(\mathrm{R}^{2}=0,00\right)$. Kasvuun vaikuttanut lämpösumma selitti melko hyvin kuiva-ainesadon määrää $\left(R^{2}=0,54\right.$; Kuva $\left.1 b\right)$. Selitysaste oli parempi kuin kasvupäivien lukumäärällä. Lannoituksesta niittoon kuluneiden päivien määrä selitti satoa hieman paremmin kuin kasvupäivien määrä $\left(R^{2}=0,35\right.$ ja $\left.R^{2}=0,31\right)$. Vaikka aineistossa oli vaihtelua sateen määrässä toisen sadon niiton jälkeen (vaihteluväli 4-60 mm; Taulukko 2), 15 vrk:n sadesummalla ei ollut vaikutusta sadon määrään $\left(\mathrm{R}^{2}=0,03\right)$. Myöskään kasvuajan keskimääräinen lämpötila tai keskimääräinen sademäärä eivät selittäneet satotasoa. Selitysastetta saatiin nostettua hieman lisäämällä toisen sadon korjuuajan lisäksi kasvupäivien lukumäärä sekä kasvuun vaikuttanut lämpösumma samaan malliin $\left(\mathrm{R}^{2}=0,76\right)$. Tällöin saatiin seuraava regressioyhtälö:

Kasato $=9151-81,6 *$ toisen sadon korjuuaika $+19,7 *$ kasvupäivien lukumäärä $-1,3 *$ kasvuun vaikuttanut lämpösumma

Aineistossa oli vaihtelua typpilannoituksen määrässä $(30-55 \mathrm{~kg} / \mathrm{ha})$, mutta typen määrällä ei ollut yhteyttä satotasoon. Tämä ei kuitenkaan tarkoita sitä, että typpilannoitusta nostamalla ei saataisi sadonlisää kolmannessa sadossa. Typen satovaikutuksen tutkimiseen tarvittaisiin kuitenkin toisenlainen koeasetelma.

Taulukko 3. Kuiva-ainesatoa selittävien regressioyhtälöiden vakiot, kulmakertoimet ja selitysasteet $\left(\mathrm{R}^{2}\right)$. Toisen ja kolmannen sadon korjuupäivät on ilmoitettu päivien lukumääränä toukokuun alusta. Sademäärä 15 vrk on laskettu alkaen toisen sadon korjuupäivästä. n=77, sademäärä 15 vrk n=75.

\begin{tabular}{lcccc} 
Muuttuja & Yksikkö & Vakio & Kulmakerroin & $\mathrm{R}^{2}$ \\
\hline Toisen sadon korjuuaika & & & & \\
Kolmannen sadon korjuuaika & vrk & 9485 & $-81,3$ & 0,72 \\
Kasvupäivien lukumäärä & vrk & 2647 & $-0,35$ & 0,00 \\
Kasvuun vaikuttanut lämpösumma & vrk & 809,0 & 35,3 & 0,31 \\
Sademäärä 15 vrk & ${ }^{\circ} \mathrm{C}$ vrk & 70,1 & 5,18 & 0,54 \\
\hline
\end{tabular}
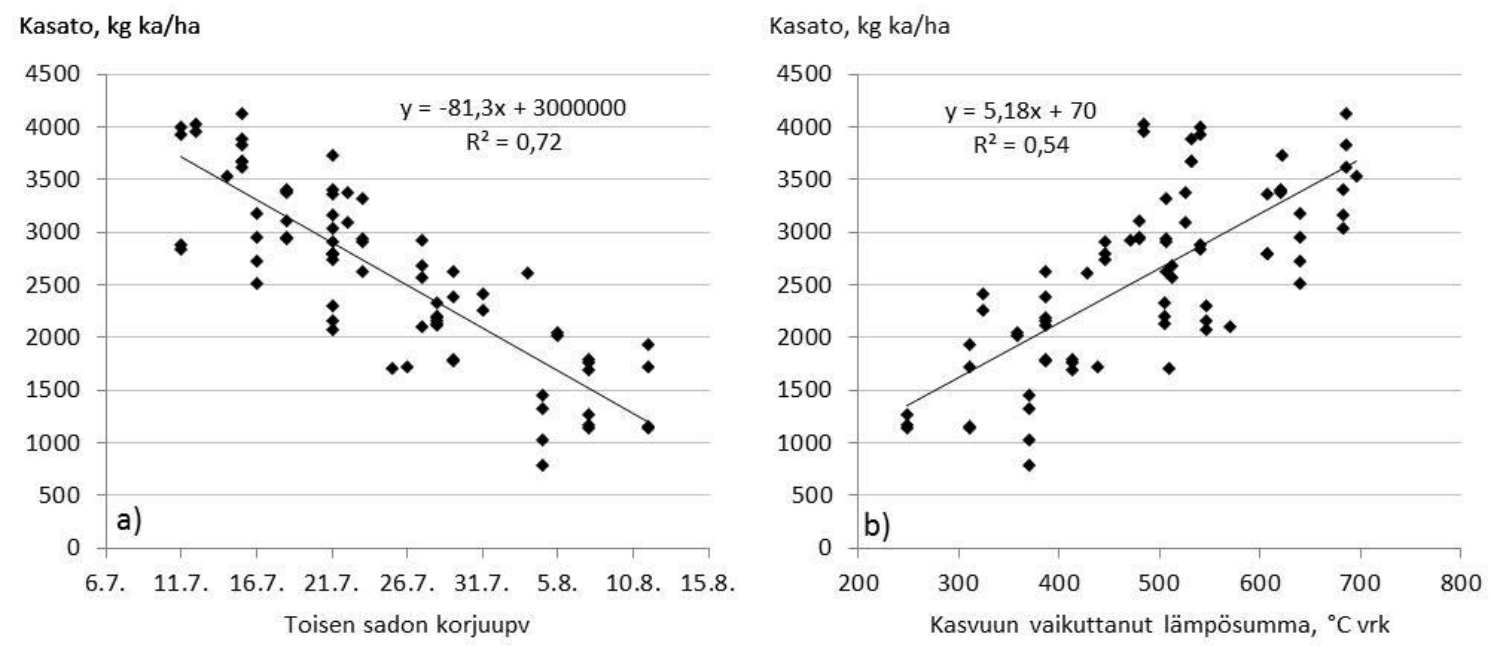

Kuva 1. Toisen sadon korjuupäivän (a) ja kasvuun vaikuttaneen lämpösumman (b) vaikutus kolmannen sadon kuiva-ainesadon kertymiseen. 


\section{Kasvunopeus}

Regressioyhtälöiden kulmakertoimista nähdään, että kolmannessa sadossa kuiva-ainesatoa kertyi havaintovälillä hehtaaria kohden keskimäärin $35,3 \mathrm{~kg} \mathrm{ka} / \mathrm{vrk}$ ja $5,18 \mathrm{~kg} \mathrm{ka} /{ }^{\circ} \mathrm{C}$ vrk (Taulukko 3). Ensimmäisessä sadossa kasvunopeuksiksi on raportoitu mm. $191 \mathrm{~kg} \mathrm{ka} / \mathrm{vrk}$ (Rinne ym. 2010) ja 161 $\mathrm{kg} \mathrm{ka} / \mathrm{ha}$ timoteillä $\left(14,9 \mathrm{~kg} \mathrm{ka} /{ }^{\circ} \mathrm{C}\right.$ vrk) ja $174 \mathrm{~kg} \mathrm{ka} / \mathrm{ha}$ ruokonadalla $\left(16,1 \mathrm{~kg} \mathrm{ka} /{ }^{\circ} \mathrm{C}\right.$ vrk) (Virkajärvi ym. 2012; samaan yksikköön käännetyt kasvunopeudet julkaisematon). Toisessa sadossa kasvunopeus oli Virkajärven ym. (2012) mukaan timoteillä $78 \mathrm{~kg} \mathrm{ka} / \mathrm{vrk}\left(6,6 \mathrm{~kg} \mathrm{ka} /{ }^{\circ} \mathrm{C}\right.$ vrk) ja ruokonadalla $83 \mathrm{~kg}$ $\mathrm{ka} / \mathrm{vrk}\left(7,0 \mathrm{~kg} \mathrm{ka} /{ }^{\circ} \mathrm{C}\right.$ vrk) (samaan yksikköön käännetyt kasvunopeudet julkaisematon). Näiden lukujen perusteella kolmannen sadon kasvunopeus niittohetkellä on alle puolet pienempi kuin toisen sadon kasvunopeus, mikä taas on noin puolet ensimmäisen sadon kasvunopeudesta. Kasvunopeudet on kaikkien niittojen osalta määritetty aikavälillä, jolloin niittoja on tehty. Etenkin kolmannen sadon kasvunopeus kasvun alkuvaiheessa on täytynyt olla selvästi nopeampaa, jotta havaittuihin kuivaainesatoihin on päästy.

Kolmannen sadon hidas kasvunopeus niittohetkellä sekä toisen sadon korjuupäivän suuri vaikutus satotasoon kertovat samasta asiasta: kolmannen sadon satotasoa voidaan nostaa tehokkaammin aikaistamalla toista korjuuta, kuin myöhästyttämällä kolmatta korjuuta. Koska kolmannen korjuun viivästyttämisellä myöhään syksyllä ei ole enää suurta satoa lisäävää vaikutusta, korjuuajan valinnassa kannattaa kiinnittää enemmän huomiota sääolosuhteisiin. Syksyllä liiallinen märkyys korjuuaikana voi pahimmassa tapauksessa estää korjuun kokonaan, jos pelto ei enää kanna korjuukalustoa. Perinteisesti on myös kehotettu välttämään niittoa 2-3 viikkoa ennen kasvukauden päättymistä (Hakkola ym. 1987), jolloin nurmen valmistautuminen talveen on kesken ja talvehtiminen voi häiriintyä.

\section{Sadon laatuominaisuudet}
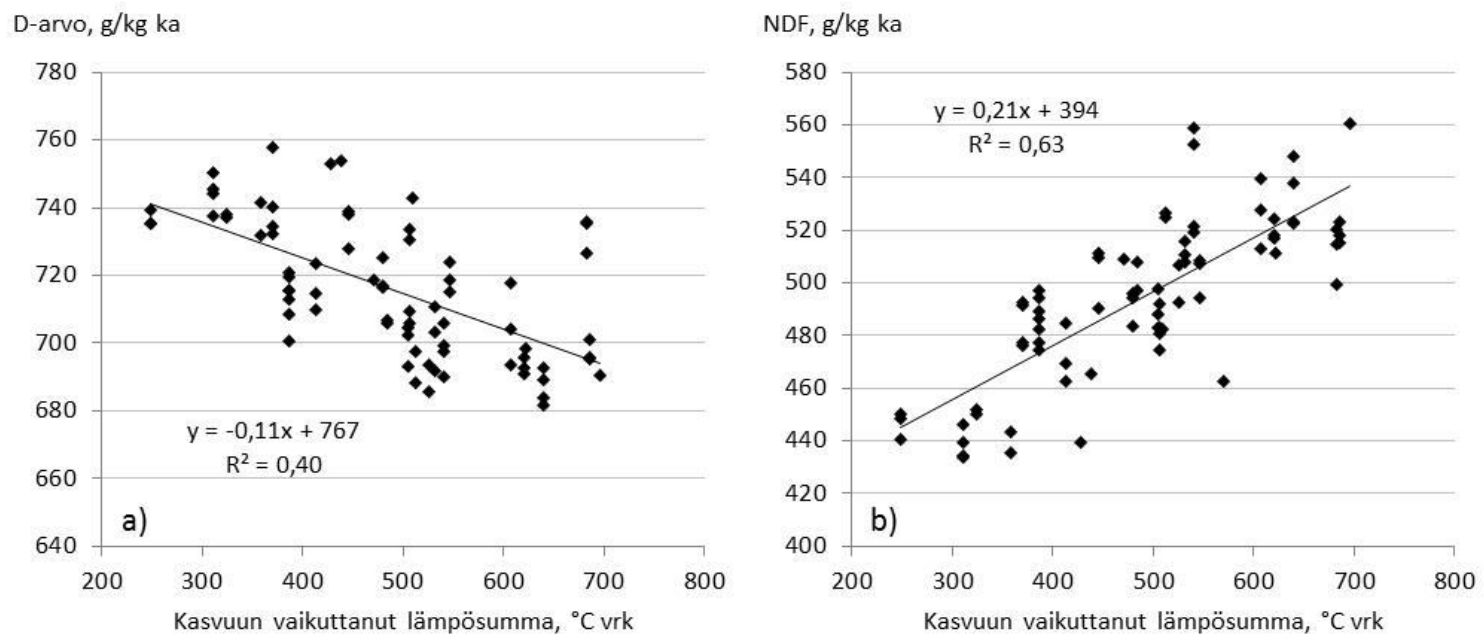

Kuva 2. Kasvuun vaikuttaneen lämpösumman vaikutus sulavuuden laskuun (a) ja NDF:n nousuun (b).

Rehutaulukoiden mukaan kolmas sato on keskimäärin hyvin sulavaa, sen NDF-pitoisuus on matala ja raakavalkuaispitoisuus korkea verrattuna ensimmäiseen ja toiseen satoon (3. sadon keskimääräinen D-arvo 700 g/kg ka, NDF 510 g/kg ka ja rv 175 g/kg ka; Rehutaulukot ja ruokintasuositukset 2015). Tässä aineistossa D-arvo ei milloinkaan alittanut arvoa $680 \mathrm{~g} / \mathrm{kg}$ ka (Kuva 2a, Taulukko 2). NDFpitoisuus oli keskimäärin $494 \mathrm{~g} / \mathrm{kg}$ ka ja rv-pitoisuus $125 \mathrm{~g} / \mathrm{kg}$ ka (Taulukko 2). Rehutaulukoiden antama rv-pitoisuus on varsin korkea ja perustuu mahdollisesti tätä aineistoa matalampiin satotasoihin. Koeruuduilta mitatut matalat raakavalkuaispitoisuudet kaikissa sadoissa selittyvät osaltaan myös karjanlannan käytön puuttumisella.

Regressioyhtälöiden kulmakertoimien perusteella 3. sadon D-arvon laskunopeus havaintovälillä oli keskimäärin $0,7 \mathrm{~g} /$ vrk (ei kuvaa, $\mathrm{R}^{2}=0,23$ ) ja $0,1 \mathrm{~g} /{ }^{\circ} \mathrm{C}$ vrk (Kuva 2a). Kuoppala (2010) raportoi 
D-arvon laskunopeudeksi ensimmäisessä sadossa keskimäärin 5,3 g/vrk ja toisessa sadossa 1,4 g/vrk. Kolmannessa sadossa sulavuuden lasku on siis huomattavan hidasta.

Muutos NDF- ja rv-pitoisuuksissa oli selkeämmin yhteydessä lämpösummaan kuin D-arvolla (Kuvat $2 \mathrm{~b}$ ja 3b). NDF-pitoisuus nousi kasvuston vanhetessa ja ylsi parhaimmillaan samoihin lukemiin keskimääräisen ensimmäisen sadon NDF-pitoisuuden kanssa $(550 \mathrm{~g} / \mathrm{kg} \mathrm{ka}$; Rehutaulukot ja ruokintasuositukset 2015). Keskimäärin NDF-pitoisuus oli siis matala, mutta korkeampiakin NDFpitoisuuksia oli mahdollista saavuttaa. Raakavalkuaisen määrä väheni kasvuston vanhetessa (Kuva 3b; $\mathrm{R}^{2}=0,52$ ). Eloperäisellä multamaalla sijainneen kokeen 2 raakavalkuaispitoisuudet poikkeavat selvästi muista satotasoon nähden korkeina (ympyröity katkoviivalla).

Kokeessa 3 havaittiin, että vaikka pitkän kasvuajan saaneessa kolmannessa sadossa oli runsaasti kuollutta solukkoa (silmämääräinen havainto), sekään ei laskenut D-arvoa alle $680 \mathrm{~g} / \mathrm{kg} \mathrm{ka}$. Kokeissa 1 ja 2 määritettiin kasvuston lehti- ja korsiosuudet eri sadoissa, ja havaittiin kolmannessa sadossa olevan selvästi vähemmän kortta muihin satoihin verrattuna (julkaisematon tulos). Sulavuus korreloi yleensä selvästi positiivisesti lehtien osuuden kanssa (mm. Lemettinen ym. 2012), mikä lienee pääsyy kolmannen sadon korkeisiin D-arvoihin. Kolmannen sadon tuotantovaikutusta tutkittaessa on kuitenkin saatu tuloksia, joissa maitotuotos ei ole ollut yhtä korkea kuin D-arvon perusteella olisi voitu olettaa (Sairanen ym. 2012). Tuotokseen vaikuttavat siis sulavuuden lisäksi myös muut tekijät, joita olisi kolmannen sadon osalta tutkittava lisää. Kuidun vähäinen määrä on myös syytä huomioida ruokintaa suunnitellessa.

\section{Typpitaseet}

Kolmannen sadon typpilannoitus pidetään yleisesti maltillisena. Yksi syy tähän on talvituhojen välttäminen, mutta käytännössä ympäristötukiehdot (maksimi 190-240 kg N/ha/v vähintään kolme satoa korjattaessa) ja nitraattidirektiivi (maksimi $250 \mathrm{~kg} \mathrm{~N} / \mathrm{ha} / \mathrm{v}$ ) rajoittavat lannoitusta. Kuvassa 3a esitetään typpitaseet luokiteltuna kahteen luokkaan lannoituksen mukaan. Korkeampi typpilannoitus nostaa tasetta, mutta myös 50-55 typpikilolla päästiin negatiivisiin taseisiin, kun satotaso on yli 2000 $\mathrm{kg} \mathrm{ka/ha}$. Nurmi on voinut saada lisätyppeä käyttöönsä maasta etenkin Ruukin sulfaattipitoisilla mailla, mutta myös Maaningalla taseet olivat yhtälailla negatiiviset lannoitustasolla $30-40 \mathrm{~kg} \mathrm{~N} / \mathrm{ha}$. Lannoitetyppeä on myös voinut jäädä käytettäväksi toisen sadon lannoituksesta. Kaikkein matalin, aineistosta poikkeavana erottuva typpitase $(-55 \mathrm{~kg} / \mathrm{ha}$; Kuva 3a) saavutettiin Ruukissa multamaalla typpilannoitustasolla $55 \mathrm{~kg} \mathrm{~N} / \mathrm{ha}$.
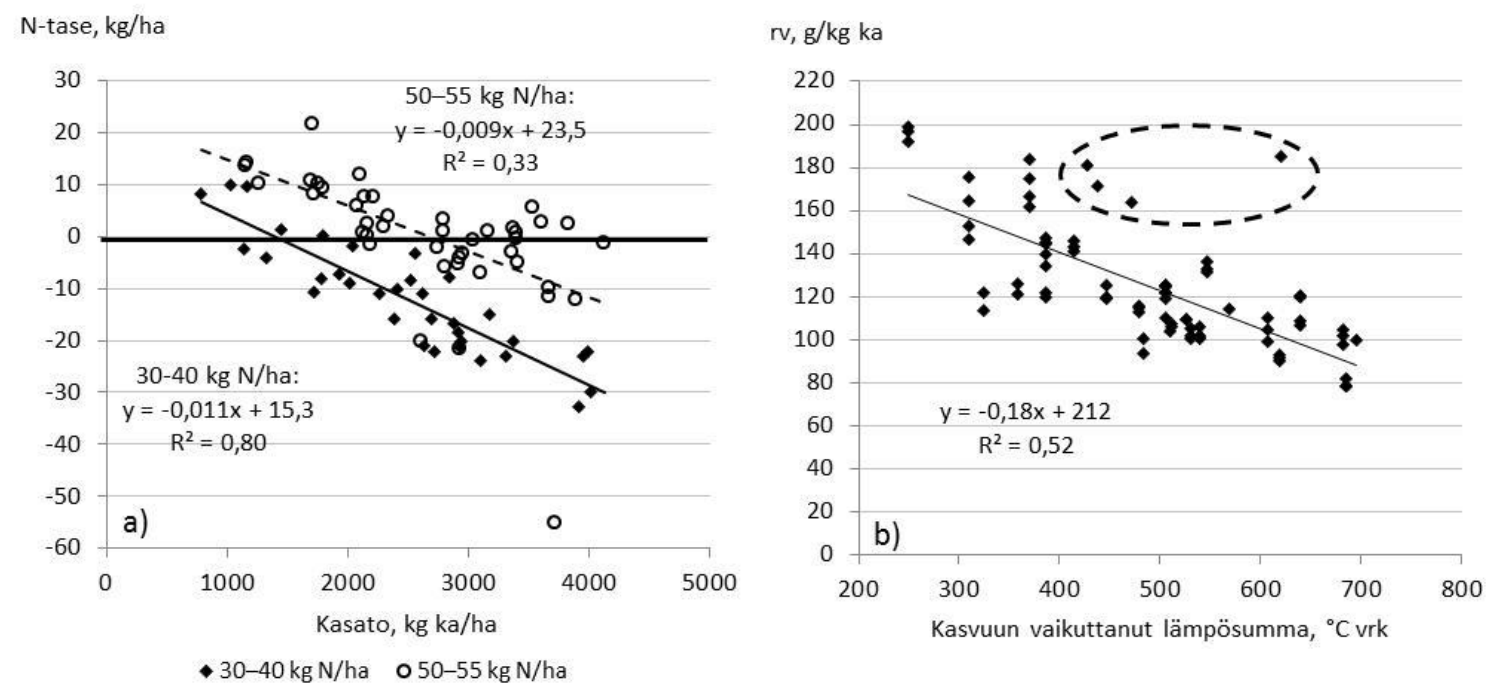

Kuva 3a. Typpitaseen (N-lannoitus - N-sato) ja kuiva-ainesadon välinen yhteys typpilannoitustasoilla $30-40 \mathrm{~kg}$ $\mathrm{N} /$ ha (kokeet 3 ja 4; n=34) ja 50-55 kg N/ha (kokeet 1,2,5 ja 6; n=43). 3b. Kasvuun vaikuttaneen lämpösumman vaikutus kolmannen sadon raakavalkuaispitoisuuteen. Katkoviivalla ympyröidyt arvot ovat Ruukin multamaalla olleelta kokeelta (koe 2). 
Tulokset osoittavat, että 30-40 kg/ha typpeä on kolmannelle sadolle liian vähän, jos halutaan välttää negatiivista typpitasetta. Jos satotaso nousee yli 2000 kuiva-ainekilon hehtaaria kohden, tase päätyy lähelle nollaa $50 \mathrm{~kg}$ typpilannoituksellakin. Jos halutaan käyttää ympäristötukiehtojen sallima maksimimäärä typpeä, kolmannen sadon typpilannoitusmäärän nostaminen vaatii ennakointia: ensimmäisen tai toisen sadon lannoitusta on vastaavasti vähennettävä. Päätökset on siis tehtävä ennen kuin sääolosuhteiden sopivuus kolmannen sadon onnistumiselle on tiedossa. Karjanlantaa käytettäessä on syytä huomioida, että ensimmäiselle tai toiselle sadolle annetusta karjanlannasta hitaammin vapautuva liukenemattomassa muodossa ollut typpi voi hyödyttää kolmannen sadon kasvua.

\section{Johtopäätökset}

Kolmannen sadon satotasoa selittivät parhaiten toisen sadon korjuuaika sekä kolmannen sadon kasvuun vaikuttanut lämpösumma. Muutokset sadon määrässä loppusyksystä ovat hitaita. Kolmannen sadon satotasoa voidaankin nostaa tehokkaammin aikaistamalla toista korjuuta kolmannen korjuun myöhästyttämisen sijaan. Kasvuston sulavuus laski lämpösumman funktiona hitaasti ja jäi aina suositusrajaa $680 \mathrm{~g} / \mathrm{kg}$ ka korkeammaksi, vaikka kuollutta solukkoa oli toisinaan runsaasti. Kuidun määrä oli keskimäärin matala. Kolmannen sadon muista sadoista poikkeavat ominaisuudet on syytä huomioida ruokintaa suunnitellessa. Typpitaseet olivat pääosin lähellä nollaa tai negatiivisia. Kolmannella sadolla voisi hyvin kasvaessaan olla potentiaalia hyödyntää nykyisin käytettyjä määriä enemmän typpilannoitusta. Korjuuajankohdan valinnassa sääolosuhteet ovat kasvuajan tai sulavuuden muutosten seuraamista tärkeämpiä. Syksyllä ongelmana ovat usein liiallinen märkyys sekä pellon kantavuusongelmat. Talvehtimisen varmistamiseen kannattaa lisäksi kiinnittää huomiota.

\section{Kirjallisuus}

Hakkola, H., Heikkilä, R., Rinne, K., \& Vuorinen, M. 1987. Odelman typpilannoitus, sängenkorkeus ja niittoaika. Maatalouden tutkimuskeskus, Tiedote 4/87.

Kuoppala K. 2010. Influence of harvesting strategy on nutrient supply and production of dairy cows consuming diets based on grass and red clover silage. Doctoral Dissertation. MTT Science 11. MTT Agrifood Research Finland, Jokioinen, Finland. 99pp.

Lemettinen, J.-P., Virkajärvi, P., Pakarinen, K., Hyrkäs, M. \& Manninen, O. 2012. Ominaisuuksien ja perimän yhteys. Teoksessa: Maarit Hyrkäs \& Perttu Virkajärvi (toim.). Nurmen kasvu- ja kehitysprosessit. NURFYS-hankkeen 2006-2011 loppuraportti. MTT Raportti 56. s.73-97.

Rehutaulukot ja ruokintasuositukset. 2015. Luonnonvara- ja biotalouden tutkimus 40/2015. Luonnonvarakeskus (Luke), Helsinki.80 s. Saatavilla: http://urn.fi/URN:ISBN:978-952-326-054-2

Rinne M., Pitkänen T., Nyholm L., Nousiainen,J. \& Huhtanen P. 2010. Nurmiheinien ensimmäisen sadon sulavuuden ja sadon määrän mallit nurmirehuntuotannon hallintaan. Teoksessa: Anneli Hopponen (toim.) Maataloustieteen päivät 2010, 12.-13.1.2010 Viikki, Helsinki: esitelmät, posterit. Suomen maataloustieteellisen seuran tiedote $26.9 \mathrm{~s}$.

Sairanen, A. \& Juutinen, E. 2012 Säilörehun korjuuajan vaikutus lehmien säilörehun syöntiin ja maitotuotokseen. Teoksessa: Nurmesta se kaikki lähtee! Karjatilan kannattava peltoviljely, KARPE-hanke 20092012. Maa- ja elintarviketalouden tutkimuskeskus. s. 4-8.

Virkajärvi P., Pakarinen K., Hyrkäs M., Seppänen M. \& Bélanger G. 2012. Tiller characteristics of timothy and tall fescue in relation to herbage mass accumulation. Crop science 52 2: 970-980. 